\title{
Design of an efficient medium for heterologous protein production in Yarrowia lipolytica: case of human interferon alpha $2 b$
}

\author{
Najla Gasmi ${ }^{1,2}$, Atef Ayed ${ }^{1}$, Jean-Marc Nicaud ${ }^{2,3}$ and Héla Kallel ${ }^{1 *}$
}

\begin{abstract}
Background: The non conventional yeast Yarrowia lipolytica has aroused a strong industrial interest for heterologous protein production. However most of the studies describing recombinant protein production by this yeast rely on the use of complex media, such media are not convenient for large scale production particularly for products intended for pharmaceutical applications. In addition medium composition can also affect the production yield. Hence it is necessary to design an efficient medium for therapeutic protein expression by this host.

Results: Five different media, including four minimal media and a complex medium, were assessed in shake flasks for the production of human interferon alpha $2 b$ ( $h I F N \alpha 2 b$ ) by Y. lipolytica under the control of POX2 promoter inducible with oleic acid. The chemically defined medium SM4 formulated by Invitrogen for Pichia pastoris growth was the most suitable. Using statistical experimental design this medium was further optimized. The selected minimal medium consisting in SM4 supplemented with $10 \mathrm{mg} / \mathrm{FeCl}{ }_{3}, 1 \mathrm{~g} / \mathrm{l}$ glutamate, $5 \mathrm{ml} / \mathrm{I}$ PTM1 (Pichia Trace Metals) solution and a vitamin solution composed of myo-inositol, thiamin and biotin was called GNY medium. Compared to shake flask, bioreactor culture in GNY medium resulted in 416-fold increase of hIFN $\alpha 2 b$ production and 2-fold increase of the biological activity.

Furthermore, SM4 enrichment with $5 \mathrm{ml} / \mathrm{I}$ PTM1 solution contributed to protect hIFN $\alpha 2 \mathrm{~b}$ against the degradation by the $28 \mathrm{kDa}$ protease identified by zymography gel in culture supernatant. The screening of the inhibitory effect of the trace elements present in PTM1 solution on the activity of this protease was achieved using a Box-Behnken design. Statistical data analysis showed that $\mathrm{FeCl}_{3}$ and $\mathrm{MnSO}_{4}$ had the most inhibitory effect.
\end{abstract}

Conclusion: We have designed an efficient medium for large scale production of heterologous proteins by $Y$. lipolytica. The optimized medium GNY is suitable for the production of hIFN $\alpha 2 \mathrm{~b}$ with the advantage that no complex nitrogen sources with non-defined composition were required.

\section{Background}

The production level of heterologous proteins greatly depends on the characteristics of the host cell, the recombinant protein to be expressed, the promoter used and most importantly on the composition of the medium, showing that production can be limited at any level.

Yarrowia lipolytica is a dimorphic ascomycete that naturally secretes several enzymes. In recent years it has attracted the attention of researchers as a model

\footnotetext{
* Correspondence: hela.kallel@pasteur.rns.tn

'Unité de Biofermentation, Institut Pasteur Tunis, 13, place Pasteur. BP 74

1002, Tunis, Tunisie

Full list of author information is available at the end of the article
}

organism in dimorphism and secretion pathway studies $[1,2]$. Furthermore, developments in genetic engineering and molecular biology make the non conventional yeast $Y$. lipolytica as one of the most promising hosts for efficient heterologous protein expression [3-5].

Although extensive data on Y. lipolytica cultivation was reported in the literature, these reports mostly describe the production of citric acid, single cell proteins or cognate proteins like lipases, and may not be always fully adapted to recombinant protein production [5-7]. Furthermore, studies on the expression of heterologous gene in this yeast rely on the use of complex media and shake-flask cultures. Nevertheless this kind of media shows numerous short-comings such as a non

\section{Biomed Central}


defined composition, a high batch-to-batch variability and a high cost. On the other hand, the majority of publications in the field of recombinant proteins production by $Y$. lipolytica report the use of the constitutive promoter hp4d [8] which can be problematic when the product being expressed is toxic to the host [4] or the use of XPR2 promoter which requires high levels of peptones in the culture medium for its full induction [9]. However the use of non-defined ingredients such as peptones is not suitable to industrial processes; for these reasons it is not only important to maximize the yield of the heterologous protein but it is essential to obtain a consistent product under the most controlled culture conditions [10].

Medium composition for $Y$. lipolytica has not been extensively studied compared to heterologous production by the yeast Pichia pastoris. Thus careful consideration of medium selection is advisable when optimizing the production of heterologous proteins particularly for pharmaceutical application, owing to its critical impact on the economy and the feasibility of the process.

In addition to conventional methods based on single factor variation used for medium optimization, statistical experimental design methodology was developed and applied for the design of new media or the screening of nutrient supplements. It is an efficient tool to identify interactions between the parameters tested, resulting therefore in a great reduction of time and cost $[11,12]$.

We described in a previous work human interferon $\alpha 2 b$ production in $Y$. lipolytica under the control of a strong inducible promoter acyl-co-enzyme A oxidase (POX2), repressed by glucose and glycerol, and induced by fatty acids and alcanes. We showed that low expression of foreign genes in $Y$. lipolytica could be attributed to several factors: the genetic design of the construct such as codon bias optimization, the use of an appropriate signal peptide and an adequate translation initiation codon environment [13]. However, besides these factors, medium composition could also affect the yield of recombinant proteins production. It was reported that the productivity of lipase by $Y$. lipolytica is affected by the presence of tryptone in the culture medium and the presence of inducers $[6,12,14]$. In the current study, we first assessed the effect of four different minimal media as well as organic nitrogen substrates on cell growth and human interferon alpha $2 \mathrm{~b}$ (hIFN $\alpha 2 \mathrm{~b}$ ) production in a recombinant strain of $Y$. lipolytica. The selected medium was then further optimized using statistical experimental design approach. Cell growth and hIFN $\alpha 2 b$ production in a 5-l bioreactor in the optimal medium using oleic acid as a carbon source and inducer, were then described.

\section{Results and Discussion}

To produce hIFN $\alpha 2 b$ in $Y$. lipolytica and to target its production into the culture medium, we had previously expressed this gene under the control of POX2 promoter inducible by oleic acid. Different sequences of the signal secretion signal of $Y$. lipolytica extracellular lipase encoded by the LIP2 gene were tested [13]. Best results were obtained with the strain JMY1852 expressing hIFN $\alpha 2 b$ with the preLIP2 signal peptide.

For media optimization studies, we first isolated a prototroph derivative of JMY1652 by its transformation with a fragment carrying the $L E U 2$ gene as described in the Material and Methods section giving rise to the strain JMY1852p which can be grown in minimal medium.

\section{Selection of an appropriate synthetic medium Classical media}

Besides classical rich medium like YPD, several defined media have been previously used for Y. lipolytica cultivation such as the medium SM1 formulated by Olssen and Johnson [15], the medium (SM2) proposed by Gordilo and coworkers [16], as well as SM3 medium described by Nicaud et al. [4]. To select the best medium for hIFN $\alpha 2 \mathrm{~b}$ production by JMY1852p strain, these media as well as the SM4 medium (designed for heterologous production in Pichia pastoris) [17] were assessed in shake-flask cultures (Figure 1).

After $72 \mathrm{~h}$ of cultivation, culture supernatants were collected, concentrated and subjected to western blot analysis using a monoclonal antibody directed towards hIFN $\alpha 2$ b; bands at approximately $19 \mathrm{kDa}$ were detected in all media except in the chemically defined medium SM3 which was then considered as unsuitable for hIFN $\alpha 2 b$ production and was withdrawn from the study (Figure $1 b)$.

The expression levels achieved in SM1 and SM2 media were very low compared to that observed in the complex medium $(\mathrm{CM})$. No hIFN $\alpha 2 \mathrm{~b}$ production was detected in cell lysates from culture pellets of hIFN $\alpha 2 b$ producing strain in all tested media (data not shown). However, a small band below the predicted size of hIFN $\alpha 2 b$ protein was observed in the supernatants of the $\mathrm{CM}$ and SM4 media (Figure 1b) which may be in favor of degradation. To check this hypothesis we performed another western blot using a polyclonal antibody directed towards hIFN $\alpha 2 \mathrm{~b}$. Two bands were detected at approximately $19 \mathrm{kDa}$ and $14 \mathrm{kDa}$ with a large amount for the second band in the case of SM1 and CM media but not for SM4 medium (Figure 1c). Hence, it seems that proteolysis affects significantly the target protein produced in these media. 

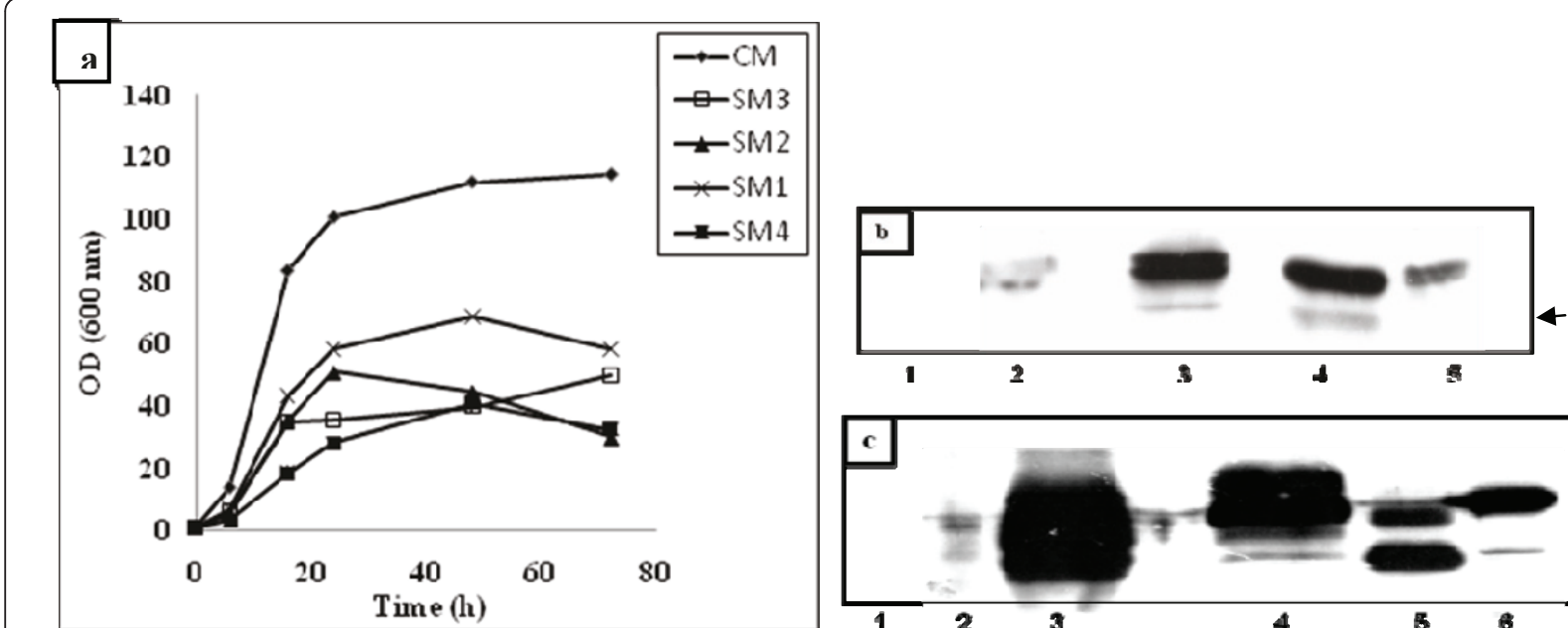

Figure 1 Cell growth and hIFN $\mathbf{\alpha} \mathbf{2 b}$ production profiles in different media culture. Time course of cell growth (a). Western blot analysis under reducing conditions using monoclonal antibody (b) and polyclonal antibody (c) directed towards hIFN $\alpha 2 \mathrm{~b}$. Lane 1, SM3; lane 2, SM2; lane 3, CM; lane 4, SM4, lane 5, SM1 and lane 6 hIFN $\alpha 2 \mathrm{~b}$ standard. The arrows indicate protein degradation. Cultures were carried in duplicate in shake flasks at $28^{\circ} \mathrm{C}$ and $180 \mathrm{rpm}$. For clarity reasons error bars are not shown.

Optical density (OD), pH and morphology changes during cultures were monitored to determine the effects of varying the culture medium. Table 1 shows data obtained for the different cultures. Comparing the chemical elemental composition of the different cultures media (Table 2) important differences can be observed. Nevertheless cell growth in SM1 medium showed a similar trend to that observed in SM2 medium, for the first 24 hours of culture. The maximal specific growth rate $(\mu)$ of the recombinant strain was equal to $0.18 \mathrm{~h}^{-1}$ in SM1 and SM2 and both media exhibited a similar biological activity which was around 2-fold lower than the level obtained in $\mathrm{CM}$ medium (Table 2). The complex medium (CM) showed a faster growth $\left(\mu=0.22 \mathrm{~h}^{-1}\right)$, a maximal biomass level of $40.1 \mathrm{~g} / \mathrm{l}$ and the highest amount of hIFN $\alpha 2 \mathrm{~b}$. However, its performance remains still lower in terms of productivity compared to the SM4 medium $\left(0.32 \times 10^{-2}\right.$ $\mathrm{mg}$ hIFN $\alpha 2 \mathrm{~b} / \mathrm{g}$ biomass vs $0.84 \times 10^{-2} \mathrm{mg} / \mathrm{g}$ ) (Table 1 ).

\section{Influence of nitrogen source on biomass and hIFN $\alpha 2 b$ production}

One of the most important parameter in media formulation is the nitrogen source. Various mineral and nitrogen compounds were evaluated as an enhancing factor of $Y$. lipolytica growth and hIFN $\alpha 2 \mathrm{~b}$ production. We had particularly studied the substitution of urea by ammonium sulfate for SM1 medium and the enrichment of SM1 and SM2 media with casaminoacids, tryptone and yeast extract. SM1 and SM2 media without any supplement were used as control.

As shown in Figure 2, substitution of urea by ammonium sulfate in SM1 increased greatly the biomass level whereas a slight enhancement was noticed for hIFN $\alpha 2 b$ production. This result differs significantly from other studies, which showed a repression of the extracellular lipase production by ammonium salts in Y. lipolytica $[6,18]$.Valuable improvements of hIFN $\alpha 2 b$ production

Table 1 Growth characteristics of $Y$. lipolytica in the different media

\begin{tabular}{|c|c|c|c|c|}
\hline & SM1 & SM2 & SM4 & $\mathrm{CM}$ \\
\hline$\mu^{a}\left(h^{-1)}\right.$ & 0.18 & 0.18 & 0.16 & 0.22 \\
\hline Maximal Biomass (g/l) & 24.01 & 17.72 & 14.26 & 40.1 \\
\hline IFN yield $(\mu \mathrm{g} / \mathrm{I})$ & 14 & 3 & 120 & 125 \\
\hline$Y_{(\mathrm{hlFN} / \mathrm{X})}(\mathrm{mg} / \mathrm{g})$ & $0.58 \times 10^{-3}$ & $0.17 \times 10^{-3}$ & $0.84 \times 10^{-2}$ & $0.32 \times 10^{-2}$ \\
\hline Residual oleic acid (g/l) & 1.4 & 0.7 & 0.54 & 1.1 \\
\hline Final pH & 3.64 & 2.72 & 3.18 & 7.78 \\
\hline Cell morphology & Mycelium & yeast cells & yeast cells & yeast cells+ \\
\hline Biological activity (UI/mg) & $0.42 \times 10^{7}$ & $0.54 \times 10^{7}$ & $0.97 \times 10^{7}$ & mycelium $1.03 \times 10^{7}$ \\
\hline
\end{tabular}

${ }_{\mu}$; growth rate calculated from total biomass level $(\mathrm{g} / \mathrm{l})$. 
Table 2 Composition of different growth media used in this study

\begin{tabular}{|c|c|c|c|c|}
\hline Components (g/l) & SM1 & SM2 & SM3 & SM4 \\
\hline $\mathrm{K}_{2} \mathrm{HPO}_{4}$ & - & 5.5 & - & - \\
\hline $\mathrm{KH}_{2} \mathrm{PO}_{4}$ & 1 & 15 & 2 & - \\
\hline $\mathrm{K}_{2} \mathrm{SO}_{4}$ & - & - & - & 18.2 \\
\hline $\mathrm{MgSO}_{4} \cdot 7 \mathrm{H}_{2} \mathrm{O}$ & 0.5 & 1 & 0.6 & 7.28 \\
\hline $\mathrm{CaCl}_{2}$ & 0.1 & - & 5 & - \\
\hline $\mathrm{NaCl}$ & 0.1 & - & - & - \\
\hline $\mathrm{CaSO}_{4}$ & - & - & - & 0.93 \\
\hline $\mathrm{KOH}$ & - & - & - & 4.4 \\
\hline$\left(\mathrm{NH}_{4}\right)_{2} \mathrm{SO}_{4}$ & - & 4 & 4.5 & - \\
\hline Urea & 2 & - & - & - \\
\hline Glucose & 20 & 20 & 20 & 20 \\
\hline $\mathrm{H}_{3} \mathrm{PO}_{4}$ & - & - & - & 26.7 \\
\hline Trace elements $(\mathrm{mg} / \mathrm{l})$ & & & & a \\
\hline $\mathrm{H}_{3} \mathrm{BO}_{3}$ & 0.5 & - & 8 & 20 \\
\hline $\mathrm{CuSO}_{4} \cdot 5 \mathrm{H}_{2} \mathrm{O}$ & 0.04 & - & 100 & 6000 \\
\hline $\mathrm{Kl}$ & 0.1 & - & 0.9 & 80 \\
\hline $\mathrm{FeCl}_{3} \cdot 4 \mathrm{H}_{2} \mathrm{O}$ & 0.2 & 10 & - & - \\
\hline $\mathrm{ZnSO}_{4} \cdot 7 \mathrm{H}_{2} \mathrm{O}$ & 0.4 & - & 4000 & - \\
\hline $\mathrm{MnSO}_{4} \cdot 2 \mathrm{H}_{2} \mathrm{O}$ & 0.4 & - & 6500 & 3000 \\
\hline EDTA & - & - & 12540 & - \\
\hline $\mathrm{NaH}_{2} \mathrm{PO}_{4} \cdot \mathrm{H}_{2} \mathrm{O}$ & - & - & 3000 & - \\
\hline $\mathrm{FeSO}_{4} \cdot 7 \mathrm{H}_{2} \mathrm{O}$ & - & - & 2500 & 6500 \\
\hline $\mathrm{Na}_{2} \mathrm{MoO}_{4} \cdot 2 \mathrm{H}_{2} \mathrm{O}$ & - & - & 4 & 200 \\
\hline $\mathrm{CoCl}_{2} \cdot 6 \mathrm{H}_{2} \mathrm{O}$ & - & - & 7 & 500 \\
\hline $\mathrm{NiSO}_{4} \cdot 7 \mathrm{H}_{2} \mathrm{O}$ & - & - & 0.8 & - \\
\hline $\mathrm{ZnCl}_{2}$ & - & - & - & 20000 \\
\hline Vitamins $(\mu \mathrm{g} / \mathrm{l})$ & & & b & \\
\hline Biotin & 8 & 8 & & 80 \\
\hline Thiamin & 200 & 100 & & - \\
\hline Myo-inositol & 4 & 2 & & - \\
\hline $\mathrm{pH}$ & 4.5 & 6 & 5.5 & 5 \\
\hline
\end{tabular}

${ }^{a}$ Concentration in the stock solution. $2 \mathrm{ml} / \mathrm{l}$ stock solution were added to SM4 medium

${ }^{\mathrm{b}}$ For SM3 medium, the vitamin solution is composed of $1 \mathrm{mg} / \mathrm{l}$ pantothenic acid, $1 \mathrm{mg} / \mathrm{l}$ nicotinic acid, $25 \mathrm{mg} / \mathrm{l} \mathrm{myo-inositol,} 1 \mathrm{mg} / \mathrm{l}$ thiamin and $1 \mathrm{mg} / \mathrm{l}$ pyridoxol hydrochloride, $0.2 \mathrm{mg} / \mathrm{l}$-amino benzoic acid and $0.05 \mathrm{mg} / \mathrm{l}$ biotin. $1.5 \mathrm{ml}$ of this solution were added to $1 \mathrm{l}$ of SM3 medium.

and biomass level were observed upon addition of organic compounds to the basal salt medium SM1 compared to the control.

For the synthetic medium SM2, cultures containing tryptone and casamino acids showed a higher biomass level compared to the control containing inorganic nitrogen source. However neither tryptone nor casamino acids were able to generate high level of hIFN $\alpha 2 b$ production. Moreover, in contrast to cell growth, the production level of hIFN $\alpha 2 b$ was enhanced over yeast extract (YE) addition. In comparison to the control, nearby 10 -fold increase was observed. These observations suggest that $\mathrm{YE}$, a complex mixture of amino acids and peptides [19], provide an alternative source of vitamins and oligo-elements for $Y$. lipolytica. Since these media are prone to fluctuations and are referred as semi-defined media, their use is not considered as costeffective and they are not recommended for large scale production of heterologous proteins [10].

\section{The Invitrogen medium}

The synthetic medium SM4 was formulated by Invitrogen Corporation (Carlsbad, CA, USA) to provide appropriate chemical and nutritional environments for Pichia pastoris growth. To our knowledge, there are no previous reports describing the use of this medium for the expression of proteins by other hosts especially by $Y$. lipolytica. Surprisingly, the expression level of the recombinant strain was dramatically improved when the strain was grown in SM4 medium; a strong band at the expected size was observed (Figure 1b). Signal densities quantification of hIFN $\alpha 2 \mathrm{~b}$ band using the Image-J software revealed that signal intensities of hIFN $\alpha 2 b$ were approximately 9 and 40-fold respectively higher than those obtained in SM1 and SM2 media and was similar to that reached in the CM medium. Table 1 shows that the yield $\mathrm{Y}_{(\mathrm{hIFN \alpha 2b} / \mathrm{X})}$ was the highest in this medium, it was 2.7-fold higher than CM. Furthermore, the biological activity of hIFN $\alpha 2 \mathrm{~b}$ in SM4 medium was the highest compared to other minimal media.

The SM4 appeared as the best medium allowing efficient hIFN $\alpha 2 \mathrm{~b}$ production in $Y$. lipolytica, by combining high productivity and activity with low level of proteolysis (Figures 1b \& 1c). SM4 as a low-cost and defined medium is ideal for large scale production. This result emphasizes the importance of evaluating various cultivation media for the production of heterologous production.

\section{Morphology and lipid accumulation}

Depending on nutritional and environmental conditions $Y$. lipolytica grows in two distinct cellular forms (mycelia and yeast like) [2,3,20]. Morphological analysis of $Y$. lipolytica recombinant strain growing in different media revealed that in $\mathrm{CM}$ medium, the strain grew as mixture of yeast-like and short mycelial cells; yeast cells were predominant (about $80 \%$ ) and pseudohyphe represented only $20 \%$. In SM1 as well as SM4 media more than $90 \%$ of the cells remained in the yeast form. However higher amounts of mycelium was obtained in SM2 medium.

Conditions that induce the dimorphic transition are extremely variable. These include the presence of specific compounds in the culture media and $\mathrm{pH}$ levels; neutral or alkaline $\mathrm{pHs}$ induce filamentation while acid $\mathrm{pH}$ favors the yeast form [1]. It has been suggested that in $Y$. lipolytica $\mathrm{pH}$ affects the formation of hyphae indirectly by modulating the availability and/or utilization of transportable sources of nitrogen. Strains without functional alkaline extracellular proteinase (AEP), an enzyme providing transportable organic sources of carbon and 


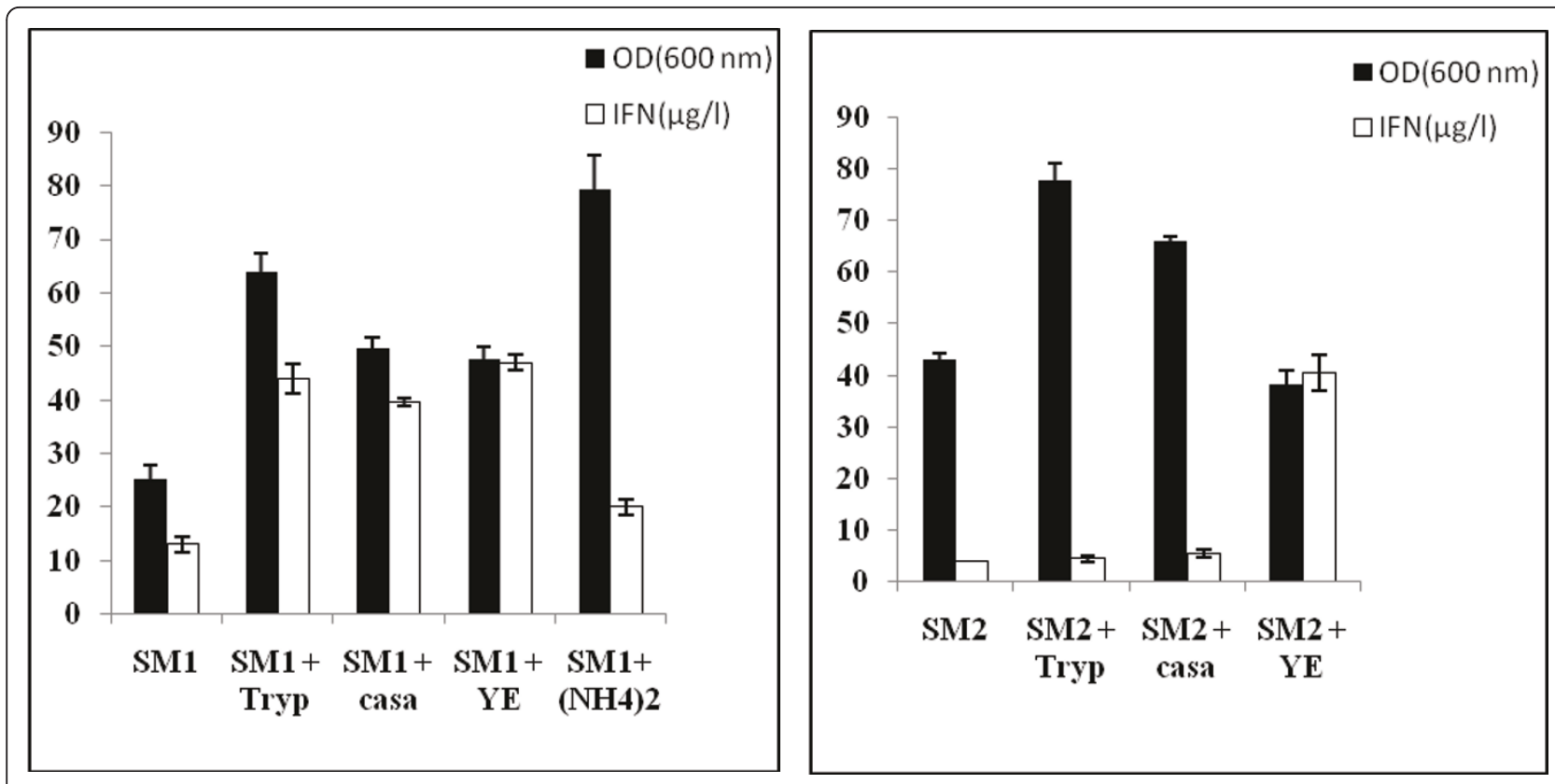

Figure 2 Effect of nitrogen source on JMY1852p growth and hIFN $\boldsymbol{\alpha} \mathbf{2 b}$ production. The recombinant strain was grown in SM1 and SM2 media supplemented with tryptone (Tryp) at $10 \mathrm{~g} / \mathrm{l}$, casaminoacids (casa) at $5 \mathrm{~g} / \mathrm{l}$ and yeast extract (YE) at $5 \mathrm{~g} / \mathrm{l}$, at $28^{\circ} \mathrm{C}$ and $180 \mathrm{rpm}$. ( $\left.\mathrm{NH}\right)_{2}$ stands for $\left(\mathrm{NH}_{4}\right)_{2} \mathrm{SO}_{4}$. Results are mean values of three independent experiments.

nitrogen to cells growing on proteinaceous substrates, which is the case of our strain, did not respond to changes in $\mathrm{pH}$ in complex medium [20]. As shown in Figures 1 and 3, there is a relation between hIFN $\alpha 2 b$ production and cell morphology. hIFN $\alpha 2 \mathrm{~b}$ expression was observed only when the yeast form was predominant. This corroborates with data reported by Madzak et al. [8] who found that higher amounts of laccase activity expressed in $Y$. lipolytica were obtained in media that exhibit a lack of mycelium formation.

In addition, protein secretion in $Y$. lipolytica could be linked to dimorphism since several genes described in the secretion pathway are also implicated in morphological transition [8].

Besides morphology, cell size was notably affected by the amount of lipid bodies accumulated. As shown in Figure 3, lipid accumulation by the recombinant strain is medium dependent. Mlikova et al. [21] showed that structural changes on the surface of $Y$. lipolytica cells grown on oleic acid result in the formation of protrusions that enable the yeast to uptake the hydrophobic compounds from the medium. The uptake of oleic acid was very efficient in the SM4 medium compared to other media; large obese cells with discernible lipid bodies appeared in the cells grown in this medium. In this case, oleic acid was not only used as an inducer of hIFN $\alpha 2 \mathrm{~b}$ production but was also stored as lipid bodies. It is worth to mention that all media were not depleted of nitrogen.
Lipid storage in yeasts could be prevented using genetic engineering tools. Four yeast genes: ARE1, $A R E 2, D G A 1$ and $L R O 1$, were found to contribute to triacylglycerol synthesis and lipid storage in Saccharomyces cerevisiae [22]. Sandager et al. [22] conducted series of genes disruption in Saccharomyces cerevisiae; they showed that the quadruple disrupted strain lost the capacity to accumulate lipids. They also demonstrated that neither lipid storage nor lipid bodies were essential for growth.

Further research, involving other strains and constructs, is needed to provide further insights about metabolic pathways of oleic acid in Y. lipolytica used for the production of heterologous proteins under the control of POX2 promoter.

\section{Adaptation of SM4 medium for optimal cultivation of Y. lipolytica}

In the much-cited SM2 medium of Gordillo et al. [16], no oligo-elements except $\mathrm{Fe}^{3+}$ were used. This indicates that $\mathrm{Fe}^{3+}$ plays a key role in $Y$. lipolytica growth and metabolism. Furthermore, we showed that only the addition of YE, containing trace elements and vitamins at a concentration of 2 to 2000 -fold higher than other organic sources, had increased significantly hIFN $\alpha 2 b$ production [23].

To further optimize SM4 medium composition, we assessed the effect of the following factors: $\mathrm{FeCl}_{3}$, vitamins solution enriched with myo-inositol and thiamin, 


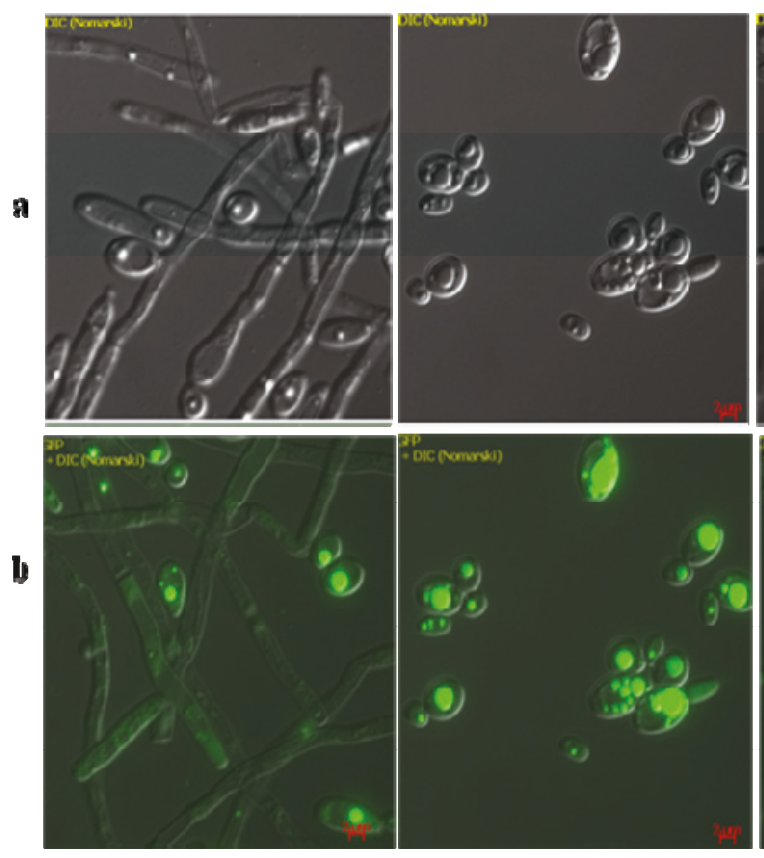

1

2

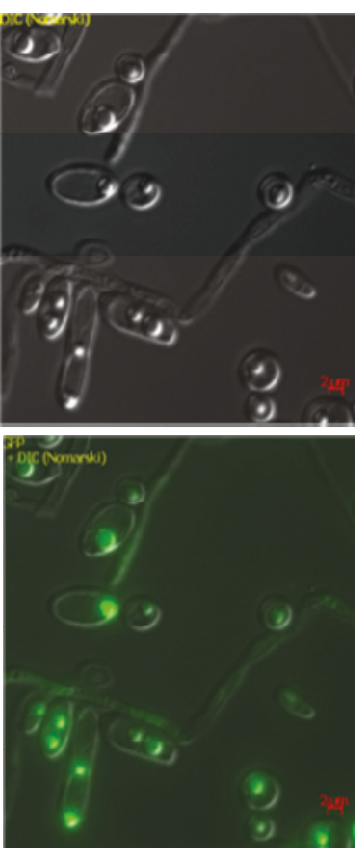

3
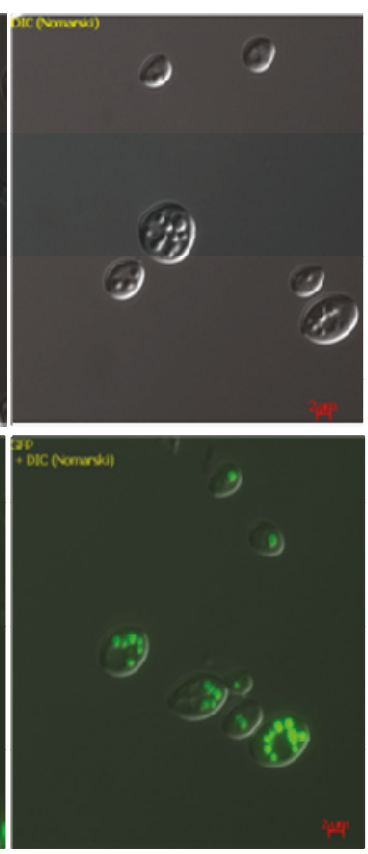

$\$$

Figure 3 Cell morphology of $\boldsymbol{Y}$. lipolytica cultures in different media. The recombinant strain was grown in SM2 (1), SM4 (2), CM (3) and SM1 (4) media. Depending on the culture medium yeast cell and/or mycelium were observed with interference contrast images (a). Micrographs were taken at $72 \mathrm{~h}$ using LipidTOXTM Green neutral lipid stains (b).

and trace-elements solution on hIFN $\alpha 2 b$ expression. Nitrogen sources namely ammonium sulfate and glutamate were also evaluated. The L8 experimental PlackettBurman matrix was applied to determine optimum conditions for hIFN $\alpha 2 b$ production by $Y$. lipolytica recombinant strain. The layout of the experiments carried out was given in Table 3.

Rates of growth were comparable for all media conditions tested (data not shown). As shown in Figure 4, among the factors studied, ammonium sulfate showed the most negative strong influence on hIFN $\alpha 2 \mathrm{~b}$ production. On the other hand, glutamate seemed to have a positive impact on the production. Glutamate is an essential precursor of protein and nucleotide synthesis.
It is also an important substrate for energy metabolism. In addition glutamate was reported as a stimulating compound for aerobic glycolysis and acetylCoA carboxylase activation [24].

Addition of thiamin, a cofactor in the pyruvate dehydrogenase complex and the alpha ketoglutaric acid dehydrogenase $[25,26]$, and myo-inositol as well as PTM1 solution (trace-elements solution, described in Table 2 for the SM4 medium) resulted in an increase of hIFN $\alpha 2 b$ yield. This suggests that vitamins and some trace elements are involved in the activity of basic enzymes responsible for oleic acid uptake and/or metabolism by $Y$. lipolytica cells. Our results correlate with those reported by Boze et al. [23] who found that

Table 3 Experimental design for SM4 optimization using Modde 6.0 software

\begin{tabular}{|c|c|c|c|c|c|c|}
\hline Exp No & Trace element & $\mathrm{FeCl}_{3}(\mathrm{mg} / \mathrm{l})$ & Glutamate $(g / l)$ & $\left(\mathrm{NH}_{4}\right)_{2} \mathrm{SO}_{4}(\mathrm{~g} / \mathrm{l})$ & Vitamins & hIFN $\alpha 2 \mathrm{~b}$ level $(\mu \mathrm{g} / \mathrm{l})$ \\
\hline 1 & PTM1 & 0 & 0 & 4 & mixture & 2.25 \\
\hline 2 & PTM1 & 10 & 0 & 0 & biotin & 135 \\
\hline 3 & PTM1 & 10 & 1 & 0 & mixture & 216 \\
\hline 4 & SM1 & 10 & 1 & 4 & mixture & 3.37 \\
\hline 5 & SM1 & 0 & 1 & 4 & biotin & 0.25 \\
\hline 6 & SM1 & 10 & 0 & 4 & biotin & 1.68 \\
\hline 7 & SM1 & 0 & 1 & 0 & mixture & 13.5 \\
\hline 8 & PTM1 & 0 & 0 & 0 & biotin & 121.5 \\
\hline
\end{tabular}

*SM1: trace elements composition in the synthetic medium 1 


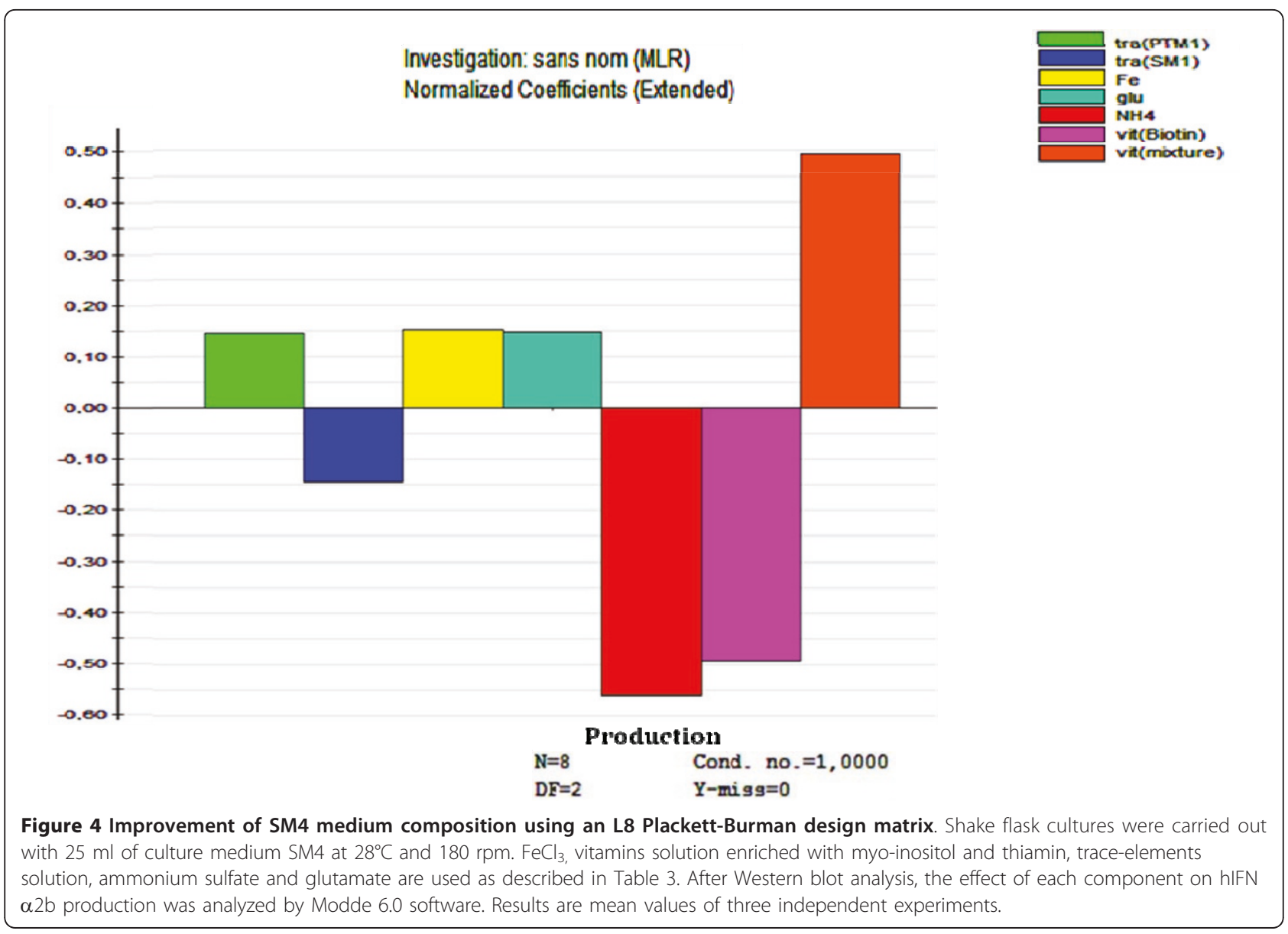

supplementation of basal medium with seven vitamins and two trace elements enhanced the growth and recombinant protein production in Pichia pastoris.

On the other hand, our study revealed that $\mathrm{FeCl}_{3}$ has a positive effect on protein expression. Indeed, DNA microarray analysis of $S$. cerevisiae yeast cells grown under iron excess or iron starvation conditions reveals a decrease in mRNA levels for many metabolic pathways protein like mitochondrial respiration, heme and biotin biosynthesis in iron depleted cells [27,28]. Transcripts coding for iron-sulfur proteins involved in the synthesis of leucine, glutamate are also diminished.

The effect of olive oil, methyloleate, and oleic acid as inducer sources of hIFN $\alpha 2 \mathrm{~b}$ production in SM4 medium was evaluated. Contrary to other strains which was enhanced by olive oil and strongly inhibited by oleic acid [12], the production pattern was very similar for all the inducers tested. Slightly improvement was obtained with oleic acid (data not shown).

The highest hIFN $\alpha 2 \mathrm{~b}$ yield was achieved in the minimal medium detailed in the experiment $\mathrm{N}^{\circ} 3$ (Table 3). Such a medium gave a hIFN $\alpha 2 b$ level that was around 2 -fold higher than SM4. This medium composed of
SM4 as a basal medium, $10 \mathrm{mg} / \mathrm{FeCl}_{3}, 1 \mathrm{~g} / \mathrm{l}$ glutamate, $5 \mathrm{ml} / \mathrm{l}$ PTM1 solution and the mixture of vitamins was called GNY medium.

\section{Effect of PTM1 solution}

Many types of yeast require for their proper propagation the presence of one or more micronutrient $[11,29]$. The effect of these elements on $Y$. lipolytica growth has not been widely investigated. In this study, the influence of PTM1 solution on cell growth and hIFN $\alpha 2 b$ production was assessed; two concentrations: $2 \mathrm{ml} / \mathrm{l}$ and $5 \mathrm{ml} / \mathrm{l}$ were tested and added to the basal salt medium SM4. In these experiments the recombinant strain was cultivated in a 5-l bioreactor in a batch mode, using oleic acid as a carbon source and inducer.

Growth rates were similar in the two culture conditions; maximal growth was reached at $24 \mathrm{~h}$ of culture followed by an immediate severe decrease of biomass. No stationary phase was observed (Figure 5Ia); this phenomenon could be explained by an excessive accumulation of lipid in cells that promotes cell lysis under high agitation. By contrast, the rate of hIFN $\alpha 2 \mathrm{~b}$ production was significantly enhanced at the highest concentration 
I
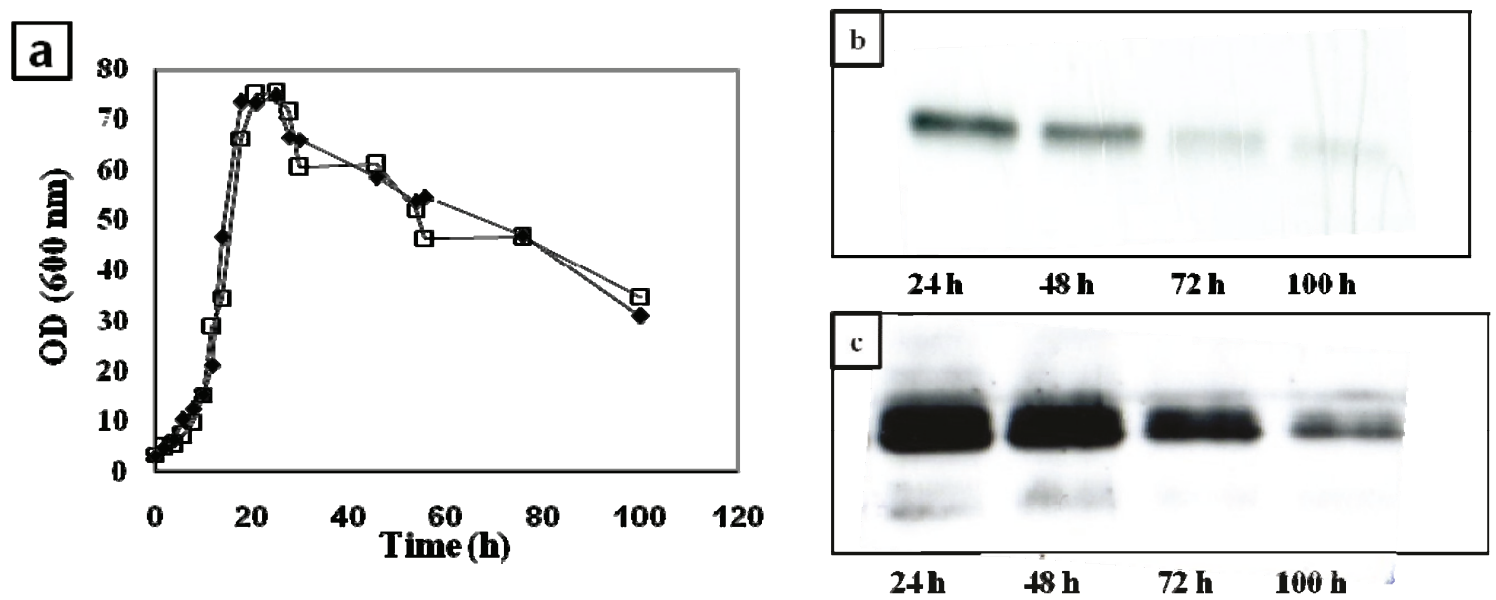

II

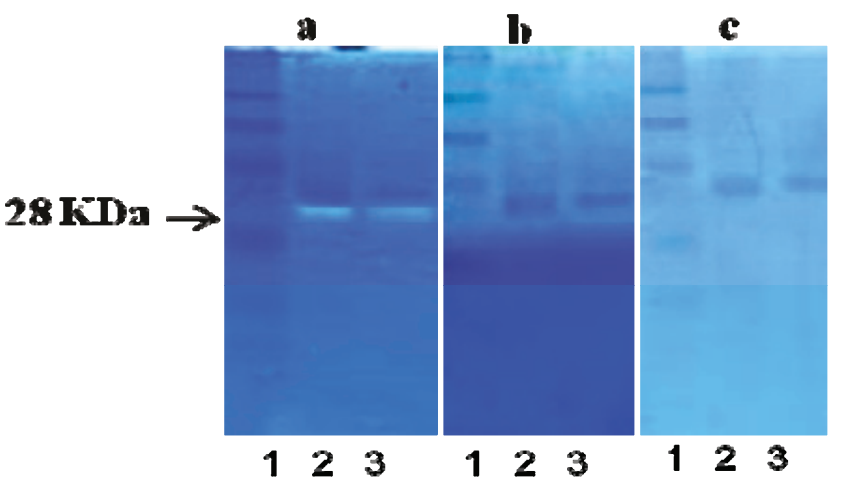

Figure 5 Effect of PTM1 concentration. (l-a) effect of PTM1 concentration on JMY1852p strain growth, hIFN $\alpha 2 \mathrm{~b}$ production using 2 ml// of PTM1 solution (I-b) and $5 \mathrm{ml} / \mathrm{I}$ of PTM1 solution (I-C). Cultures were carried in 5-I bioreactor with oleic acid as carbon and inducer source, data represent the mean of duplicate. Open triangle: $5 \mathrm{ml}$ PTM1 addition; closed triangle: $2 \mathrm{ml}$ PTM1 addition. (II-a) a 28 kDa protease detected in cultures supernatants (SN). Lane 1; molecular weight, lane 2; SN (5 ml/I PTM1), lane 3; SN (2 ml/I PTM1). Protease inhibition by pepstatin addition at $10 \mu \mathrm{M}(\mathrm{II}-\mathrm{b})$ and $5 \mathrm{ml} / \mathrm{l}$ of PTM1 addition (II-c).

of PTM1. Figure 5Ib showed that the production was reduced to up $80 \%$ when PTM1 was supplemented to the culture medium at $2 \mathrm{ml} / \mathrm{l}$ especially, after $48 \mathrm{~h}$ of growth which correlates with the beginning of the decline phase and the release of proteases due to cell lysis compared to the medium containing $5 \mathrm{ml} / \mathrm{l}$ of PTM1 solution.

To investigate whether differences in hIFN $\alpha 2 b$ expression could be explained by protease degradation, supernatants from cultures were subjected to zymographic analysis. Several substrates, such as casein, gelatin and bovine serum albumin were used as substrate; a $28 \mathrm{kDa}$ protease with casein specificity was identified at $\mathrm{pH} 5$ in the two culture conditions. Colorimetric method with azocasein substrate, a chromogenic derivative of casein, showed no proteolytic activity at the start of cultures, appearance of proteases started at $20 \mathrm{~h}$, their concentrations increased with increased cell concentration and at the end of cultures. A drastic increase of the target protein level was observed. Therefore, it seems likely that PTM1 solution appear to protect hIFN $\alpha 2 b$ against this protease (data not shown).

The effect of inhibitor supplementation on protease activity was studied; zymographies of samples showed no activity with pepstatin at $10 \mu \mathrm{M}$. Surprisingly complete inhibition of the proteolytic activity occurred upon addition of PTM1 at $5 \mathrm{ml} / \mathrm{l}$ in the enzymatic reaction (Figure $5 \mathrm{II}$ ). This result explains the low degradation in SM4 medium compared to data obtained in the other media (Figure 1c). The effect observed for PTM1 solution has not been reported previously which could be a solution to alleviate some proteolysis problems. 
To further characterize the inhibition of hIFN $\alpha 2 b$ degradation by PTM1, the experimental Box-Behnkan design was applied, the effects of the eight components present in PTM1 solution $\left(\mathrm{H}_{3} \mathrm{BO}_{3} ; \mathrm{CuSO}_{4} .5 \mathrm{H}_{2} \mathrm{O} ; \mathrm{KI}\right.$; $\mathrm{MnSO}_{4} \cdot 2 \mathrm{H}_{2} \mathrm{O} ; \mathrm{FeSO}_{4} \cdot 7 \mathrm{H}_{2} \mathrm{O} ; \mathrm{Na}_{2} \mathrm{MoO}_{4} \cdot 2 \mathrm{H}_{2} \mathrm{O} ; \mathrm{Co}$ $\mathrm{Cl}_{2} \cdot 6 \mathrm{H}_{2} \mathrm{O}$ and $\mathrm{ZnCl}_{2}$ ) and their interactions were investigated; 67 experiments were conducted according to the lay out detailed in Table 4. Proteolytic activity was measured by the colorimetric azocasein method. Experimental data were statistically analyzed by Modde 6.0 software to identify the effect of each factor and interaction studied.

As shown in Figure 6, among all various trace elements tested, $\mathrm{FeCl}_{3}$ and $\mathrm{MnSO}_{4}$ have the most inhibitory effect on the proteases followed by $\mathrm{KI}, \mathrm{CuSO}_{4}$ and $\mathrm{Na}_{2} \mathrm{MoO}_{4}$. Others elements like $\mathrm{CoCl}_{2}, \mathrm{ZnCl}_{2}$ have a less pronounced effect whereas $\mathrm{H}_{3} \mathrm{BO}_{3}$ acted in the opposite way. Furthermore, $\mathrm{FeCl}_{3}$ without $\mathrm{MnSO}_{4}$ or $\mathrm{MnSO}_{4}$ without $\mathrm{FeCl}_{3}$, showed an inhibition of the proteolysis. Similar data were observed for $\mathrm{H}_{3} \mathrm{BO}_{3} \times \mathrm{ZnCl}_{2}$, $\mathrm{CoCl}_{2} \times \mathrm{FeCl}_{3}, \mathrm{CoCl}_{2} \times \mathrm{KI}, \mathrm{ZnCl}_{2} \times \mathrm{MnSO}_{4}, \mathrm{FeCl}_{3} \times \mathrm{KI}$, $\mathrm{KIxMnSO}_{4}, \mathrm{KIxCuSO}_{4}, \mathrm{MnSO}_{4} \mathrm{xCuSO}_{4}$ and $\mathrm{FeCl}_{3} \mathrm{x}$ $\mathrm{Na}_{2} \mathrm{MoO}_{4}$ interactions. Other interactions showed a weaker inhibitory effect (Figure 6). These data indicate the positive effect of some mineral ions for the improvement of heterologous protein expression by the non conventional yeast $Y$. lipolytica.

Literature review shows that these ions could have an activating or inhibiting role in protein production [11,29]. Zhang et al. [29] reported that bivalent cations such as $\mathrm{Mn}^{2+}$ and $\mathrm{Mg}^{2+}$ increased the production of extrasucrase by Escherichia coli whereas $\mathrm{Zn}^{2+}, \mathrm{Fe}^{2+}$ and $\mathrm{Cu}^{2+}$ have an opposite effect. Nevertheless, the enhancement of protein production via proteolytic inhibition as described in this study has not been reported previously.

\section{Bioreactor culture in GNY medium}

The effect of the new formulated medium GNY on hIFN $\alpha 2 \mathrm{~b}$ production by $Y$. lipolytica recombinant strain under the control of the inducible fatty acid promoter POX2 was investigated in a batch bioreactor culture, under controlled conditions as described in the material and methods section. Two phases cultivation was conducted, the first one is a cell growth with glucose as carbon source and the second one is the induction of hIFN $\alpha 2 b$ biosynthesis with oleic acid.

Kinetics of biomass and hIFN $\alpha 2 \mathrm{~b}$ expression over $120 \mathrm{~h}$ of culture on $2 \%$ oleic acid was monitored. After $24 \mathrm{~h}$ of culture on $20 \mathrm{~g} / \mathrm{l}$ glucose, the biomass reached $20 \mathrm{~g} \mathrm{DW} / \mathrm{l}$ and $35 \mathrm{~g} / \mathrm{l}$ once oleic acid was used as an inducer. Culture supernatants were analyzed by Western blot under reducing conditions, hIFN $\alpha 2 \mathrm{~b}$ production was initiated after 2 $\mathrm{h}$ of induction. Maximum yield of hIFN $\alpha 2 \mathrm{~b}$ was equal to $50 \mathrm{mg} / \mathrm{l}$ with a biological activity of $2.1 \times 10^{7} \mathrm{IU} / \mathrm{mg}$.
Table 4 Lay out of the experiments conducted to study the effect of PTM1 components on protease activity

\begin{tabular}{|c|c|c|c|c|c|c|c|c|}
\hline Exp No & h3 & co & $\mathrm{zn}$ & fe & $k$ & $\mathrm{mn}$ & $\mathrm{cu}$ & na \\
\hline 1 & $p$ & $p$ & $p$ & $p$ & $\mathrm{p}$ & $p$ & a & a \\
\hline 2 & a & $p$ & $p$ & $p$ & $p$ & $p$ & $p$ & $\mathrm{p}$ \\
\hline 3 & $p$ & a & $p$ & $p$ & $p$ & $p$ & $p$ & $p$ \\
\hline 4 & a & a & $p$ & $p$ & $p$ & $p$ & a & a \\
\hline 5 & $\mathrm{p}$ & $p$ & $\mathrm{a}$ & $p$ & $p$ & $p$ & $p$ & a \\
\hline 6 & a & $p$ & a & $p$ & $p$ & $p$ & a & $p$ \\
\hline 7 & $\mathrm{p}$ & a & $\mathrm{a}$ & $p$ & $\mathrm{p}$ & $\mathrm{p}$ & a & $\mathrm{p}$ \\
\hline 8 & a & a & a & $p$ & $p$ & $p$ & $p$ & a \\
\hline 9 & $p$ & $p$ & $p$ & a & $p$ & $p$ & $p$ & a \\
\hline 10 & a & $p$ & $p$ & a & $p$ & $p$ & a & $p$ \\
\hline 11 & $p$ & a & $p$ & a & $p$ & $p$ & a & $p$ \\
\hline 12 & a & a & $p$ & a & $\mathrm{p}$ & $p$ & $p$ & a \\
\hline 13 & $p$ & $p$ & a & a & $p$ & $p$ & a & a \\
\hline 14 & $\mathrm{a}$ & $p$ & $\mathrm{a}$ & a & $p$ & $p$ & $p$ & $p$ \\
\hline 15 & $p$ & a & a & a & $p$ & $p$ & $p$ & $p$ \\
\hline 16 & a & a & a & a & $p$ & $p$ & a & a \\
\hline 17 & $p$ & $p$ & $p$ & $p$ & a & $p$ & $\mathrm{a}$ & $p$ \\
\hline 18 & a & $p$ & $\mathrm{p}$ & $p$ & a & $\mathrm{p}$ & $p$ & a \\
\hline 19 & $p$ & a & $p$ & $p$ & a & $p$ & $p$ & a \\
\hline 20 & $\mathrm{a}$ & a & $p$ & $p$ & a & $\mathrm{p}$ & $\mathrm{a}$ & $p$ \\
\hline 21 & $p$ & $p$ & a & $p$ & a & $p$ & $p$ & $p$ \\
\hline 22 & a & $p$ & a & $p$ & a & $p$ & $\mathrm{a}$ & a \\
\hline 23 & $\mathrm{p}$ & a & $\mathrm{a}$ & $p$ & a & $p$ & $\mathrm{a}$ & a \\
\hline 24 & a & a & a & $p$ & a & $p$ & $p$ & $p$ \\
\hline 25 & $p$ & $p$ & $p$ & $a$ & $a$ & $p$ & $p$ & $p$ \\
\hline 26 & a & $p$ & $p$ & a & a & $p$ & a & a \\
\hline 27 & $p$ & $\mathrm{a}$ & $p$ & a & $\mathrm{a}$ & $p$ & $\mathrm{a}$ & $\mathrm{a}$ \\
\hline 28 & a & $\mathrm{a}$ & $p$ & a & $\mathrm{a}$ & $p$ & $p$ & $p$ \\
\hline 29 & $\mathrm{p}$ & $p$ & $\mathrm{a}$ & a & a & $p$ & $\mathrm{a}$ & $p$ \\
\hline 30 & a & $p$ & a & a & $\mathrm{a}$ & $p$ & $p$ & a \\
\hline 31 & $p$ & a & $\mathrm{a}$ & a & $\mathrm{a}$ & $\mathrm{p}$ & $p$ & $\mathrm{a}$ \\
\hline 32 & a & $\mathrm{a}$ & a & a & $\mathrm{a}$ & $p$ & a & $p$ \\
\hline 33 & $p$ & $p$ & $p$ & $p$ & $p$ & $a$ & $a$ & $p$ \\
\hline 34 & $a$ & $p$ & $p$ & $p$ & $p$ & $a$ & $p$ & $a$ \\
\hline 35 & $p$ & $\mathrm{a}$ & $p$ & $p$ & $p$ & $\mathrm{a}$ & $p$ & a \\
\hline 36 & a & $\mathrm{a}$ & $p$ & $p$ & $p$ & a & a & $\mathrm{p}$ \\
\hline 37 & $p$ & $p$ & $\mathrm{a}$ & $p$ & $p$ & $\mathrm{a}$ & $p$ & $p$ \\
\hline 38 & $\mathrm{a}$ & $p$ & $\mathrm{a}$ & $p$ & $p$ & $\mathrm{a}$ & $\mathrm{a}$ & $a$ \\
\hline 39 & $p$ & a & $\mathrm{a}$ & $p$ & $p$ & $\mathrm{a}$ & $\mathrm{a}$ & a \\
\hline 40 & a & a & $\mathrm{a}$ & $p$ & $\mathrm{p}$ & $\mathrm{a}$ & $p$ & $\mathrm{p}$ \\
\hline 41 & $p$ & $p$ & $p$ & a & $p$ & a & $p$ & $p$ \\
\hline 42 & $a$ & $p$ & $p$ & $a$ & $p$ & $a$ & $\mathrm{a}$ & $a$ \\
\hline 43 & $p$ & $a$ & $p$ & a & $p$ & a & $\mathrm{a}$ & a \\
\hline 44 & a & $\mathrm{a}$ & $p$ & $\mathrm{a}$ & $p$ & $\mathrm{a}$ & $p$ & $p$ \\
\hline 45 & $p$ & $p$ & $\mathrm{a}$ & $\mathrm{a}$ & $p$ & a & $\mathrm{a}$ & $p$ \\
\hline 46 & $a$ & $p$ & $a$ & $a$ & $p$ & $a$ & $p$ & $a$ \\
\hline
\end{tabular}


Table 4 Lay out of the experiments conducted to study the effect of PTM1 components on protease activity (Continued)

\begin{tabular}{|c|c|c|c|c|c|c|c|c|}
\hline 47 & $p$ & a & $a$ & $a$ & $p$ & a & $p$ & a \\
\hline 48 & $a$ & $\mathrm{a}$ & $a$ & $a$ & $p$ & $a$ & $a$ & $p$ \\
\hline 49 & $p$ & $p$ & $p$ & $p$ & $a$ & $a$ & $a$ & a \\
\hline 50 & $a$ & $p$ & $p$ & $\mathrm{p}$ & $a$ & a & $p$ & $p$ \\
\hline 51 & $p$ & a & $p$ & $p$ & a & a & $p$ & $p$ \\
\hline 52 & a & $\mathrm{a}$ & $p$ & $p$ & $a$ & a & a & a \\
\hline 53 & $p$ & $p$ & $\mathrm{a}$ & $p$ & $a$ & $a$ & $p$ & a \\
\hline 54 & $a$ & $p$ & $a$ & $p$ & a & $a$ & $a$ & $p$ \\
\hline 55 & $p$ & $a$ & $a$ & $p$ & $a$ & $a$ & $a$ & $p$ \\
\hline 56 & a & a & a & $p$ & $a$ & a & $p$ & a \\
\hline 57 & $p$ & $p$ & $p$ & a & $a$ & a & $p$ & a \\
\hline 58 & $\mathrm{a}$ & $p$ & $p$ & a & a & a & a & $p$ \\
\hline 59 & $\mathrm{p}$ & $a$ & $p$ & $a$ & $a$ & $a$ & $a$ & $p$ \\
\hline 60 & a & $a$ & $p$ & $a$ & $a$ & $a$ & $p$ & a \\
\hline 61 & $\mathrm{p}$ & $p$ & a & $a$ & a & a & a & a \\
\hline 62 & a & $p$ & $a$ & a & $a$ & $a$ & $p$ & $p$ \\
\hline 63 & $p$ & a & a & $\mathrm{a}$ & a & $\mathrm{a}$ & $p$ & $p$ \\
\hline 64 & $a$ & $a$ & $a$ & $a$ & $a$ & $a$ & $a$ & a \\
\hline 65 & $p$ & $p$ & $p$ & $p$ & $p$ & $p$ & $p$ & $p$ \\
\hline 66 & $\mathrm{p}$ & $p$ & $p$ & $p$ & $p$ & $p$ & $p$ & $\mathrm{p}$ \\
\hline 67 & $p$ & $p$ & $p$ & $p$ & $p$ & $p$ & $p$ & $p$ \\
\hline
\end{tabular}

The experiments were designed by Modde 6.0 software.

Abbreviations: h3 $\left(\mathrm{H}_{3} \mathrm{BO}_{3}\right)$; cu $\left(\mathrm{CuSO}_{4} .5 \mathrm{H}_{2} \mathrm{O}\right) ; \mathrm{k}(\mathrm{KI}) ; \mathrm{mn}\left(\mathrm{MnSO}_{4} .2 \mathrm{H}_{2} \mathrm{O}\right)$; fe $\left(\mathrm{FeSO}_{4} .7 \mathrm{H}_{2} \mathrm{O}\right)$; na $\left(\mathrm{Na}_{2} \mathrm{MoO}_{4} \cdot 2 \mathrm{H}_{2} \mathrm{O}\right) ; \mathrm{co}\left(\mathrm{CoCl}_{2} \cdot 6 \mathrm{H}_{2} \mathrm{O}\right)$ and $\mathrm{zn}\left(\mathrm{ZnCl}_{2}\right)$. (p) means presence and (a) stands for absence.

Compared to shake flask procedure, culture in bioreactor did not permit to enhance significantly the biomass yield however it generates a drastically higher expression level. Over 416-fold increase of hIFN $\alpha 2 \mathrm{~b}$ concentration and 2-fold enhancement of the biological activity were obtained. This is the first study describing this amount of increase; only 8-20 fold increase in heterologous protein expression has been reported in $Y$. lipolytica when scaling-up cultures from shake flask to bioreactor [5,8]. However, the fold of increase of the biological activity of hIFN $\alpha 2 b$ observed was not proportional to the increase of the production level. Biological activity of hIFN $\alpha 2 \mathrm{~b}$ can be influenced by several factors such as the post-translational modifications; any factor that interferes or favors the binding of this cytokine to its receptor, impacts the bioactivity of hIFN $\alpha 2 b$ [30]. Therefore, further structural studies are needed to give deeper insights about this result.

\section{Conclusions}

Conventional methods as well as statistical experimental designs were used in this study to select and optimize a minimal defined medium for $Y$. lipolytica heterologous protein expression. The optimized medium GNY is suitable for the production of hIFN $\alpha 2 \mathrm{~b}$ by $Y$. lipolytica JMY1852p with the advantage that no complex nitrogen sources with non-defined composition were required. Nutritional composition of the culture medium especially trace elements plays an important role in the improvement of protein production. GNY appears as an attractive medium for heterologous production in $Y$. lipolytica. Besides hIFN $\alpha 2 \mathrm{~b}$ production, the expression of other therapeutic proteins by this host cultivated in GNY medium is currently under investigation. Promising results could be expected from a more complete optimization strategy of growth and induction conditions in bioreactor.

\section{Materials and methods Microorganism}

The auxotrophic, recombinant strain of $Y$. lipolytica Po1d (JMY 1852) with the genotype [MATA, leu2-270, ura3-302, xpr2-322, pox2- preLip2-IFNop-URA3], producing heterologous hIFN $\alpha 2 \mathrm{~b}$ was constructed previously [13]. The synthetic gene optimized for its codon bias was expressed under the control of the POX2 promoter which is induced by oleic acid. In this study, a prototrophic derivative was obtained by transformation with a SalI fragment carrying the LEU2 gene. This latter prototrophic strain was called JMY $1852 \mathrm{p}$ and used throughout the present investigation.

\section{Chemicals}

Chemicals were purchased from Sigma-Aldrich (St. Louis, MO, USA) except oleic acid which was provided by Prolab (Quebec, Canada). Thiamin was from Merck (Darmstadt, Germany) and Myo-inositol was from Calibiochem (La Jolla, Canada).

\section{Media}

The recombinant strain was isolated on YPD-agar (Yeast Peptone Dextrose) medium (20 g/l glucose; $10 \mathrm{~g} / \mathrm{l}$ yeast extract; $10 \mathrm{~g} / \mathrm{l}$ peptone and $20 \mathrm{~g} / \mathrm{l}$ agar) and was grown in complex rich medium $\mathrm{Y}_{1} \mathrm{~T}_{2} \mathrm{D}_{1} \mathrm{O}_{2}$ or in defined media. The $\mathrm{Y}_{1} \mathrm{~T}_{2} \mathrm{D}_{1} \mathrm{O}_{2}$ medium consisting of $10 \mathrm{~g} / \mathrm{l}$ yeast extract, $20 \mathrm{~g} / \mathrm{l}$ bactotryptone, $20 \mathrm{~g} / \mathrm{l}$ glucose and $2 \%$ (W/V) oleic acid was buffered with $50 \mathrm{mM}$ sodium phosphate buffer, $\mathrm{pH}=6.8$. The compositions of the four mineral media used in this study are described in Table 2.

Media pHs were adjusted at the required values with $\mathrm{NaOH}(5 \mathrm{~N})$ or ammonia prior to sterilization. The trace elements and vitamins solutions, sterilized by filtration, were added to the culture media as described in the text.

Oleic acid was added to these media to a final concentration of $20 \mathrm{~g} / \mathrm{l}$. Stock solution (20\% oleic acid, $0.5 \%$ Tween 20) was subjected to sonication for 2 min with a 


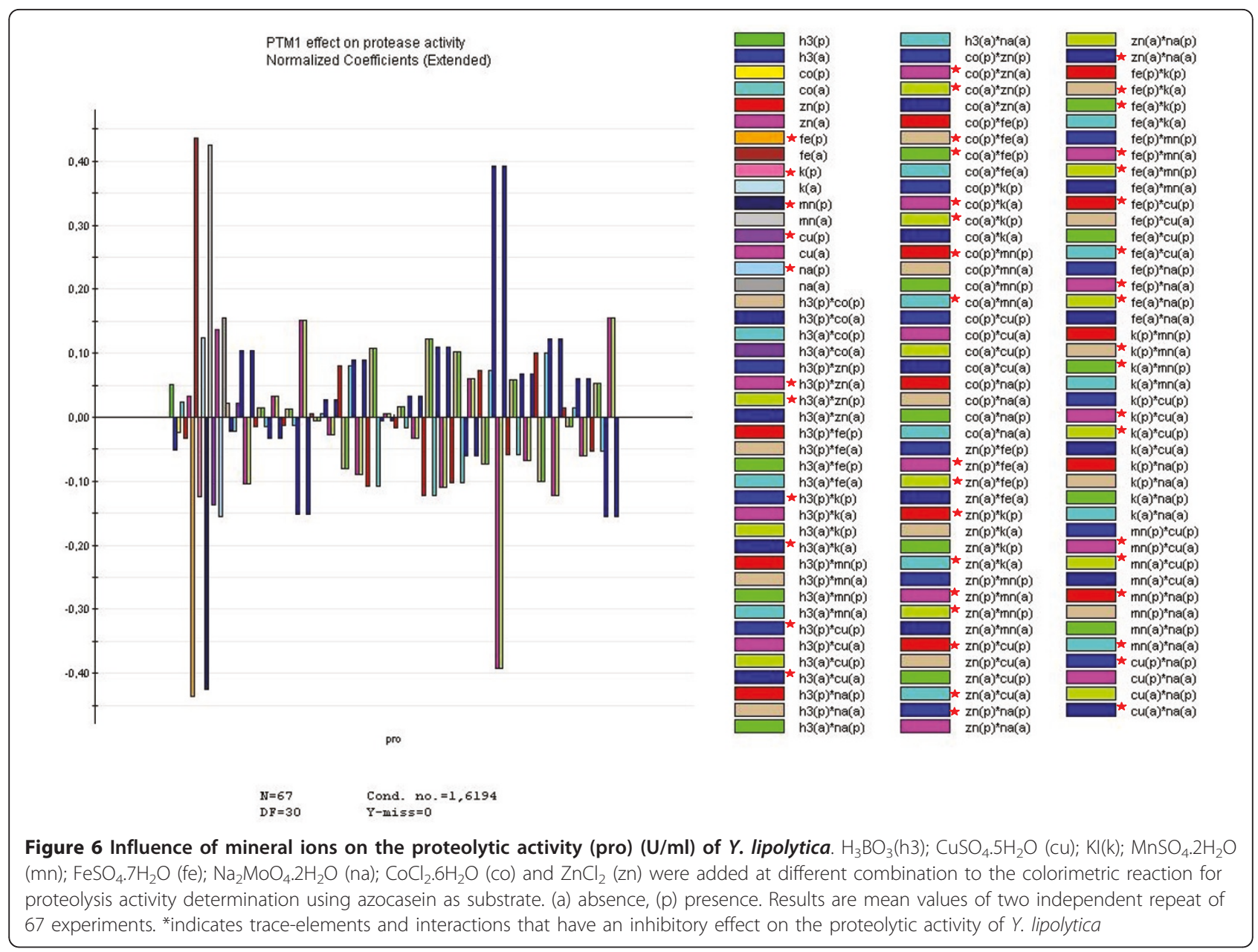

BANDELIN SONOPLUS sonicator (Berlin, Germany) for emulsification purpose.

\section{Culture conditions}

For all experiments, pre-inocula were grown on YPD medium. Cells in mid-exponential growth $\left(16 \mathrm{~h}\right.$ at $28^{\circ} \mathrm{C}$ and $180 \mathrm{rpm}$ ) were centrifuged, washed twice with $50 \mathrm{mM}$ phosphate buffer, $\mathrm{pH} 6.8$ and used to inoculate the culture at an initial optical density at $600 \mathrm{~nm}$ (OD $600 \mathrm{~nm}$ ) of 0.4 . All cultures were performed at least in duplicate.

Shake flask cultures were carried out in $250 \mathrm{ml}$ baffled Erlenmeyer flasks with $25 \mathrm{ml}$ of culture medium and incubated at $28^{\circ} \mathrm{C}$ at $180 \mathrm{rpm}$. Samples were taken at various time intervals to monitor cell growth and hIFN $\alpha 2 b$ level. For purification purpose, cultures were dispensed in $250 \mathrm{ml}$ volumes into 2 -l baffled shake flasks. To study the effect of organic nitrogen source, media were enriched with either $10 \mathrm{~g} / \mathrm{l}$ of tryptone, or $5 \mathrm{~g} / \mathrm{l}$ of yeast extract or $5 \mathrm{~g} / \mathrm{l}$ casamino acids.

Cultures were carried out in a 5-1 bioreactor (Infors, Switzerland) with working volume of 21 . After sterilization at $121^{\circ} \mathrm{C}$ for $30 \mathrm{~min}$, the medium was inoculated with 200 $\mathrm{ml}$ of pre-culture at an initial OD $600 \mathrm{~nm}$ culture of 0.3 . Culture was performed at $28^{\circ} \mathrm{C}$, aeration rate of $1.5 \mathrm{vvm}$ and agitation speed of $600 \mathrm{rpm}$. Samples for the determination of the production and cell dry weight were withdrawn at $2 \mathrm{~h}$ interval. Oleic acid concentration was estimated by the colorimetric method based on a sulfophospho-vanillin reaction described by Frings and Dunn (1970) [31]. Biomass was monitored either by measuring optical density $\left(\mathrm{OD}_{600}\right)$ or by dry weight (DW) determination. One unit of OD was found to be equivalent to $0.3 \mathrm{~g} / \mathrm{l}$ DW. When cells were grown on media containing oleic acid, samples were extracted with $2 / 5(\mathrm{~V} / \mathrm{V})$ of propanol/ butanol solution prior to optical density determination.

\section{Determination of protease activity Colorimetric method}

Protease activity was determined by the colometric method using azocasein as a substrate. Culture supernatant $(10 \mu \mathrm{l})$ was mixed with $10 \mu \mathrm{l}$ of a $2.5 \%$ azocasein solution and $70 \mu \mathrm{l}$ of $0.1 \mathrm{M}$ phosphate-citrate buffer $\mathrm{pH}$ 5 then incubated at $28^{\circ} \mathrm{C}$ for $1 \mathrm{~h}$. The reaction was stopped by addition of $350 \mu \mathrm{l}$ of $10 \%$ TCA (Trichloro 
acetic acid) solution. Samples were centrifuged at 13.000 rpm for $10 \mathrm{~min}$, and then the absorbances of the supernatant were read at $440 \mathrm{~nm}$ against the blank. One unit of protease activity was defined as the amount of enzyme required for an increase in absorbance by 0.01 per hour.

\section{Zymographies}

For zymographic analysis, 15\% separating gels were mixed with $5 \mathrm{mg}$ casein; samples were treated with three-fold concentrated sample buffer. Gels were run at constant current of $100 \mathrm{mv}$ Afterwards the gels were rinsed three time with $2.5 \%(\mathrm{~V} / \mathrm{V})$ Triton $\mathrm{X}-100$ and incubated overnight in $50 \mathrm{mM}$ acetate buffer $\mathrm{pH} 5$ with or without inhibitors or metals $\left(\mathrm{CaCl}_{2} 5 \mathrm{mM}, \mathrm{ZnCl}_{2} 1\right.$ $\mu \mathrm{M}, \mathrm{PTM} 1)$ [32]. Gels were stained with coomassie blue and then destained until transparent zones caused by proteolytic digestion of the protein substrate in the gel, are visible against a blue background.

\section{SDS-PAGE and Western blot analysis}

Sodium dodecyl sulfate polyacrylamide gel electrophoresis (SDS-PAGE) was performed in $15 \%$ polyacrylamide gels under denaturating conditions as described by Laemmli [33] Proteins secreted into the medium and collected after $72 \mathrm{~h}$ of culture, were concentrated by microcon (Millipore, Bedford, MA, USA). After separation, proteins were stained with coomassie brilliant blue R 250.

Prestained broad range protein marker RPN756 (GE Healthcare, Uppsala, Sweden) was utilized for estimation of proteins molecular sizes.

For western blot analysis, $10 \mu \mathrm{l}$ of concentrated supernatant were separated by SDS-PAGE and transferred onto nitrocellulose membranes (Millipore, Bedford, MA, USA) by electroblotting. The membranes were blocked with PBS-5\% skimmed milk, 0.1\% Tween 20 overnight at $4^{\circ} \mathrm{C}$. Membranes were incubated for 1 hour with antihuman IFN- $\alpha$ monoclonal antibody produced in-house and diluted to $1 / 500$ followed by incubation with a goat anti-mouse IgG peroxidase conjugated monoclonal antibody (Sigma, St Louis, USA) diluted at 1/5000 or with polyclonal antibody also produced in-house and diluted to $1 / 200$. The immunoreactive protein was visualized by ECL (GE Healthcare, Uppsala, Sweden). Western blots were scanned and analyzed by J-image software (Image-J 1.42) to determine the area of each band. hIFN $\alpha 2 b$ was quantified using a calibration curve established with purified hIFN- $\alpha 2 \mathrm{~b}$ produced in Pichia pastoris.

\section{Fluorescence microscopy}

To visualize lipid bodies, LipidTOX ${ }^{\mathrm{TM}}$ Green neutral lipid stains $(2.5 \mathrm{mg} / \mathrm{ml}$ in ethanol from Invitrogen) was added to a cell suspension that has an OD 600 of 5. Microscopy was performed with a fluorescence microscope AXIO
Imager.M1 (Zeiss, Le Pecq, France) at $495 \mathrm{~nm}$ with a 100 $\times$ oil immersion objective. AxioVision Rel. 4.6 software was used for recording the images.

\section{Biological activity}

The biological activity of the hIFN $\alpha 2 \mathrm{~b}$ preparation was determined by gene report assay as described by Meager [34]. Briefly HEK (Human Embryo Kidney) 293P cell line stably transfected with IFN-inducible promoter sequence (ISRE, Interferon Stimulated Response Element) linked to SEAP gene (secreted alkaline phosphatase) and exposed to human IFN $\alpha$ increase expression of the reporter gene product in direct relation to the dose of human IFNa. The readout is a measure of this product's enzymatic action. hIFN $\alpha 2 \mathrm{~b}$ reference standard (code: 95/566) was kindly provided by Dr Meager (NIBSC, United Kingdom).

\section{Experimental design}

The software Modde 6.0 (Umetrics, Sweden) was used in this study for the design of the experiments and statistical analysis of the data. This approach was previously applied for other optimization studies in our laboratory [35].

To identify the significant factors that affect the response (hIFN $\alpha 2 \mathrm{~b}$ yield, proteolytic activity), normalized coefficients are calculated by the software. To make the coefficients comparable when responses have different ranges, the coefficients are normalized, that is the coefficients are divided by the standard deviation of their respective response. The overview plot displays the coefficients values for the response as bar graphs. This plot shows therefore how the factors affect the response. Coefficient values higher than zero indicate that factor/ interaction studied has a positive effect on the response; the highest the coefficient, the more important is the contribution of factor/interaction studied. On the opposite negative values show that the response is impaired by the factor/interaction studied.

\section{Acknowledgements}

The authors wish to acknowledge EGIDE for their financial support in the frame of the CMCU project France Tunisia (grant N. 07G0913).

\section{Author details}

'Unité de Biofermentation, Institut Pasteur Tunis, 13, place Pasteur. BP 74 1002, Tunis, Tunisie. '2INRA, UMR1319 Micalis, Domaine de Vilvert, F-78352 Jouy-en-Josas, France. ${ }^{3}$ CNRS, UMR1319 Micalis, Domaine de Vilvert, F-78352 Jouy-en-Josas, France.

\section{Authors' contributions}

NG carried out the experiments, performed the statistical design and drafted the manuscript. AA participated in bioreactor cultures and biological activity tests. JMN supervised clones design and selection and reviewed the manuscript. HK conceived the study, coordinated he experiments and reviewed the final manuscript. All authors read and approved the final manuscript. 


\section{Declaration of competing interests}

The authors declare that they have no competing interests.

Received: 14 December 2010 Accepted: 20 May 2011

Published: 20 May 2011

\section{References}

1. Ruiz-Herrera J, Sentandreu R: Different effectors of dimorphism in Yarrowia lipolytica. Archives of Microbiology 2002, 178:477-483.

2. Szabo R: Dimorphism in Yarrowia lipolytica: filament formation is suppressed by nitrogen starvation and inhibition of respiration. Folia Microbiol (Praha) 1999, 44:19-24

3. Barth G, Gaillardin C: Yarrowia lipolytica. In Nonconventional Yeasts in Biotechnology. Edited by: Wolf K. Springer-Verlag, Berlin; 1996:313-388.

4. Nicaud JM, Madzak C, van den Broek P, Gysler C, Duboc P, Niederberger P, Gaillardin C: Protein expression and secretion in the yeast Yarrowia lipolytica. FEMS Yeast Res 2002, 2:371-379.

5. Madzak C, Gaillardin C, Beckerich JM: Heterologous protein expression and secretion in the non-conventional yeast Yarrowia lipolytica. Biotechnol 2004, 109:63-81.

6. Fickers P, Nicaud JM, Gaillardin C, Destain J, Thonart P: Carbon and nitrogen sources modulate lipase production in the yeast Yarrowia lipolytica. J Appl Microbiol 2004, 96:742-749.

7. Turki S, Kraeim IB, Weeckers F, Thonart P, Kallel H: Isolation of bioactive peptides from tryptone that modulate lipase production in Yarrowia lipolytica. Bioresour Technol 2010, 2724-31.

8. Madzak C, Otterbein L, Chamkha M, Moukha S, Asther M, Gaillardin C, Beckerich JM: Heterologous production of a laccase from the basidiomycete Pycnoporus cinnabarinus in the dimorphic yeast Yarrowia lipolytica. FEMS Yeast Res 2005, 5:635-46.

9. Ogrydziak DM, Scharf SJ: Alkaline extracellular protease produced by Saccharomycopsis lipolytica CX161-1B. J Gen Microbiol 1982, 128:1225-1234

10. Goodey AR: The production of heterologous plasma proteins. Trends Biotechnol 1993, 11:430-3.

11. Rosso AM, Ferrarotti SA, Krymkiewicz N, Nudel BC: Optimisation of batch culture conditions for cyclodextrin glucanotransferase production from Bacillus circulans DF 9R. Microb Cell Fact 2002, 12.

12. Corzo G, Revah S: Production and characteristics of the lipase from Yarrowia lipolytica 681. Bioresource Technology 1999, 70:173-180.

13. Gasmi N, Fudalej F, Kallel H, Nicaud JM: A molecular approach to optimize hIFN alpha $2 \mathrm{~b}$ expression and secretion in Yarrowia lipolytica. Appl Microbiol Biotechnol 2011, 89:109-119.

14. Turki S, Ayed A, Chalghoumi N, Weekers F, Thonart P, Kallel H: An enhanced process for the production of a highly purified extracellular lipase in the non-conventional yeast Yarrowia lipolytica. Appl Biochem Biotechnol 2009, 160:1371-85.

15. Olssen $B$, Johnson M: Factors producing high yeast yields in synthetic media. J Bacteriol 1948, 57:235-243.

16. Gordillo MA, Sanz A, Sànchez A, Valero F, Montesinos JL, Lafuente J, Solà C: Enhancement of Candida rugosa lipase production by using different control fed-batch operational strategies. Biotechnol Bioeng 1998, 60:156-168.

17. Cos O, Ramón R, Montesinos $J$, Valero F: Operational strategies, monitoring and control of heterologous protein production in the methylotrophic yeast Pichia pastoris under different promoters. Microbial Cell Factories 2006, 5-17.

18. Novotný C, Dolezalovà $L$, Musil $P$, Novàk M: The production of lipase by some Candida and Yarrowia yeasts. J Basic Microbiol 1988, 4:221-227.

19. Singleton P, Sainsbury D: Dictionary of microbiology and molecular biology. Wiley, New York; 21987

20. Szabo R, Stofaníková V: Presence of organic sources of nitrogen is critical for filament formation and $\mathrm{pH}$-dependent morphogenesis in Yarrowia lipolytica. FEMS Microbiol Lett 2002, 206:45-50.

21. Mlícková K, Roux E, Athenstaedt K, d'Andrea S, Daum G, Chardot T, Nicaud JM: Lipid accumulation, lipid body formation, and acyl coenzyme A oxidases of the yeast Yarrowia lipolytica. Appl Environ Microbiol 2004, 70:3918-24.

22. Sandager $L$, Gustavsson $M H$, Ståh $U$, Dahlqvist A, Wiberg E, Banas A Lenman M, Ronne H, Stymne S: Storage Lipid Synthesis Is Non-essential in Yeast. J Biological Chemistry 2002, 277:6478-6482.
23. Boze H, Laborde C, Chemardin P, Richard F, Venturing C, Combarnous $Y$ Moulin G: High-level secretory production of recombinant porcine follicle-stimulating hormone by Pichia pastoris. Process Biochemistry 2001 36:907-913.

24. Lan WZ, Qin WM, Yu LJ: Effect of glutamate on arachidonic acid production from Mortierella alpine. Letters in Applied Microbiology 2002, 35:357-360.

25. Van Niel EWJ, Hahn-Hagerdal B: Nutrient requirements of lactococci in defined growth media. Appl Microbiol Biotechnol 1999, 52:617-627.

26. Zhou J, Zhou H, Du G, Liu L, Chen J: Screening of a thiamine-auxotrophic yeast for alpha-ketoglutaric acid overproduction. Lett Appl Microbiol 2010, 51(3):264-71

27. Shakoury-Elizeh M, Tiedeman J, Rashford J, Ferea T, Demeter J, Garcia E, Rolfes R, Brown PO, Botstein D, Philpott CC: Transcriptional remodeling in response to iron deprivation in Saccharomyces cerevisiae. Mol Biol Cell 2004, 5:1233-43.

28. Puig S, Askeland E, Thiele DJ: Coordinated remodeling of cellular metabolism during iron deficiency through targeted mRNA degradation. Cell 2005, 120:99-110.

29. Zhang $H B$, Mao XQ, Wang YJ, Hu XQ: Optimization of culture conditions for high-level expression of dextransucrase in Escherichia coli. International Journal of Food, Agriculture and Environment 2009, 7:75-78.

30. Grace MJ, Lee S, Bradshaw S, Chapman J, Spond J, Cox S, Delorenzo M Brassard D, Wylie D, Cannon-Carlson S, Cullen C, Indelicato S, Voloch M, Bordens R: Site of pegylation and polyethylene glycol molecule size attenuate interferon-alpha antiviral and antiproliferative activities through the JAK/STAT signaling pathway. J Biol Chem 2005, 280(8):6327-36.

31. Frings C, Dunn R: Colorimetric method for determination of total serum lipids based on the sulfo-phospho-vanillin reaction. American Journal of Clinical Pathology 1970, 53:89-91.

32. Ikonomoul L, Peeters-Joris C, Schneider YJ, Agathos SN: Supernatant proteolytic activities of High-Five insect cells grown in serum-free culture. Biotechnology letters 2002, 24:965-969.

33. Laemmli UK: Cleavage of structural proteins during the assembly of the head of the bacteriophage T4. Nature 1970, 227:680-685.

34. Meager A: Measurement of cytokines by bioassays: theory and application. Methods 2006, 38:237-52

35. Rourou S, van der Ark A, van der Velden T, Kallel H: Development of an animal-component free medium for Vero cells culture. Biotechnology Progress 2009, 25:1752-61.

doi:10.1186/1475-2859-10-38

Cite this article as: Gasmi et al:: Design of an efficient medium for heterologous protein production in Yarrowia lipolytica: case of human interferon alpha 2b. Microbial Cell Factories 2011 10:38.

\section{Submit your next manuscript to BioMed Central and take full advantage of:}

- Convenient online submission

- Thorough peer review

- No space constraints or color figure charges

- Immediate publication on acceptance

- Inclusion in PubMed, CAS, Scopus and Google Scholar

- Research which is freely available for redistribution

Submit your manuscript at www.biomedcentral.com/submit
C Biomed Central 